Original Article

\title{
Exploration of Zingiber officinale effects on growth performance, immunity and gut morphology in broilers
}

\author{
Exploração dos efeitos do Zingiber officinale no desempenho de crescimento, \\ imunidade e morfologia intestinal em frangos de corte
}

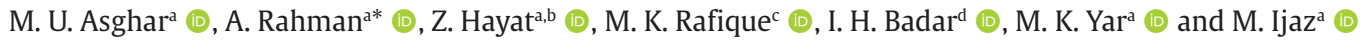 \\ aUniversity of Veterinary and Animal Sciences, Department of Animal Sciences, Lahore, Pakistan \\ bUniversity of Sargodha, College of Agriculture, Department of Animal Sciences, Sargodha, Pakistan \\ cUniversity of Veterinary and Animal Sciences, Department of Pathobiology, Lahore, Pakistan \\ dUniversity of Veterinary and Animal Sciences, Department of Meat Sciences, Lahore, Pakistan
}

\begin{abstract}
The current study aimed to determine the effects of different levels of Zingiber officinale as a herbal feed additive on growth performance, carcass characteristic, serum biochemistry, total bacterial count (TBC), gut morphology, and immunological parameters of broilers. A total of 1500, day-old broiler chicks (Hubbard) were equally accredited to five treatment groups, each with six replicates (50 birds/replicate). Five experimental diets were prepared using basal diet i.e. with antibiotics positive control (PC), $3 \mathrm{~g} / \mathrm{kg}$ ginger (group A), $6 \mathrm{~g} / \mathrm{kg}$ ginger (group B), $9 \mathrm{~g} / \mathrm{kg}$ ginger (group $C$ ) and without antibiotics negative control (NC). Group A and C showed significantly $(p<0.05)$ higher feed intake $(\mathrm{FI})$ as compared to other groups. Group $\mathrm{C}$ showed significantly $(\mathrm{p}<0.05)$ lower Total bacterial count (TBC) followed by group B as compared to NC. Carcass characteristics showed non-significant effects among different treatments. Mean villi length and width were significantly $(\mathrm{p}<0.05)$ higher in all ginger supplemented groups as compared to the control groups. Blood serum parameters including cholesterol, triglycerides, and lowdensity lipoproteins (LDL) were significantly $(\mathrm{p}<0.05)$ lower in groups $\mathrm{B}$ and $\mathrm{C}$ in comparison with the control groups. Whereas high-density lipoproteins (HDL) was significantly higher in group B as compared to the others. In conclusion, ginger supplementation @0.6\% in the basal diet significantly improved growth performance and gut morphometry of broilers. It also showed a positive impact on cholesterol, triglycerides and gut microbes. Therefore, ginger could be a better substitute for antibiotic growth promoters.
\end{abstract}

Keywords: broiler, cholesterol, ginger, performance, phytobiotics.

\begin{abstract}
Resumo
O presente estudo teve como objetivo determinar os efeitos de diferentes níveis de Zingiber officinale como aditivo à base de plantas medicinais sobre o desempenho de crescimento, características da carcaça, bioquímica sérica, contagem bacteriana total (CBT), morfologia intestinal e parâmetros imunológicos de frangos de corte. Um total de 1.500 pintos de corte de um dia de idade (Hubbard) foram igualmente credenciados em cinco grupos de tratamento, cada um com seis repetições (50 aves/repetição). Cinco dietas experimentais foram preparadas usando dieta basal, ou seja, com controle positivo de antibióticos (PC), $3 \mathrm{~g} / \mathrm{kg}$ de gengibre (grupo A), $6 \mathrm{~g} / \mathrm{kg}$ de gengibre (grupo B), $9 \mathrm{~g} / \mathrm{kg}$ de gengibre (grupo $C$ ) e sem controle negativo de antibióticos (NC). Os grupos A e C apresentaram consumo de ração (FI) significativamente $(\mathrm{p}<0,05)$ maior do que os outros grupos. $O$ grupo $C$ apresentou contagem bacteriana total (CBT) significativamente menor ( $p<0,05)$ seguido pelo grupo B em comparação com o NC. As características da carcaça apresentaram efeitos não significativos entre os diferentes tratamentos. 0 comprimento e largura médios das vilosidades foram significativamente $(p<0,05)$ maiores em todos os grupos suplementados com gengibre em comparação com os grupos de controle. Os parâmetros séricos do sangue, incluindo colesterol, triglicerídeos e lipoproteínas de baixa densidade (LDL), foram significativamente ( $p<0,05$ ) menores nos grupos B e C em comparação com os grupos controle. Enquanto as lipoproteínas de alta densidade (HDL) foram significativamente maiores no grupo B em comparação com os outros. Em conclusão, a suplementação de gengibre a 0,6\% na dieta basal melhorou significativamente o desempenho de crescimento e a morfometria intestinal de frangos de corte. Ele também mostrou um impacto positivo sobre o colesterol, triglicerídeos e micróbios intestinais. Portanto, o gengibre pode ser um substituto melhor para os promotores de crescimento com antibióticos.
\end{abstract}

Palavras-chave: frango, colesterol, gengibre, desempenho, fitobióticos.

*e-mail: abdurrehman@uvas.edu.pk

Received: March 26, 2021 - Accepted: June 26, 2021

This is an Open Access article distributed under the terms of the Creative Commons Attribution License, which permits unrestricted use, distribution, and reproduction in any medium, provided the original work is properly cited. 


\section{Introduction}

The poultry sector has confronted numerous problems and difficulties such as inefficient feed utilization, poor performance and development, poor feed conversion ratio, retailed price variation, and several infectious and parasitic diseases (Khan and Iqbal, 2016). The protein demand of the developing countries is increasing with the population growth. Therefore, the competence of the poultry business to meet up the protein needs of people in developing countries can't be embellished. Furthermore, higher demand and cost of traditional feed resources such as fish meal, corn, soya bean and groundnut cake are decreasing the effective consumption of poultry meat. These feed resources are also directly competing with human food. Therefore, it is expected the demand and supply of traditional feed resources are likely to rise in the coming years. This scenario is giving a fascinating reason to determine the utility of generally available substitute feed components.

From the past years, antibiotics had been used as a growth regulator in the poultry sector resulting in ideal growth and production. Antibiotics as feed additives were identified as a precautionary application in 1940. Currently, the use of antibiotics resulted in the development of resistance in certain bacterial species like Escherichia coli and Salmonella against antibiotics (Cosby et al., 2015; Phiri et al., 2020; Varga et al., 2019). Therefore, currently, the transfer of these antibiotic-resistant bacteria to humans via poultry meat has become a major issue. Moreover, the consumption of antibiotics has been strictly banned in many European countries and there is a complete necessity to exclude their use as a growth regulator in other countries as well (Waldroup et al., 2003).

In the exploration of safe and effective substitutes for growth regulators, a series of researches have been conducted. Natural additives like plant and plant extracts are likely to use because they are harmless, effective, consistent, and suitable among consumers. For attaining maximum growth in broilers, the diet must be balanced with food additives to comply with nutrient-enriched balanced feed. Feed additives refer to the agents which enhance the development, growth, and efficiency of animals by the effective consumption of feed nutrients (Pirgozliev et al., 2019). For the optimization of growth and development, many types of herbal feed additives have been used which are usually utilized in broilers feed (Zhang et al., 2009).

Herbal feed additives are much appropriate as growth regulators because of less increase in cost, low poisoning risk, minimum health issues, and friendliness of the atmosphere. Herbs play an outstanding role in weight expansion, improving feed conversion ratio (FCR), and also weakening morbidity (Devegowda, 1996). Traditionally, numerous medicinal plants such as Pimpinella anisum $L$ and poppy have been used to improve the immune system, production performance and antioxidant capacity in poultry (Bayram et al., 2007, 2008; Kucukkurt et al., 2009). Various dietary herbs, the extract and bark of plants, and essential oils had been observed to check their actions against microorganisms along with their abilities as growth promoters in poultry (Cross et al., 2007). Hence, these medicinal herbs have been used for broilers feed to improve their growth performance, the effectiveness of feed conversion ratio, features of carcass and meat standard in the birds, along with improved feed economics. Furthermore, medicinal plants with certain active biological elements enhanced the process of digestion and help in stimulating the functions of the immune system in the broilers (Ghazalah and Ali, 2008). Ginger (Zingiber officinale), is considered an herbal additive, a pharmaceutical natural herb, and a source of food spice (Chrubasik et al., 2005).

Ginger is one of the most frequently used herbs among medicinal plants Worldwide. Ginger is usually referred to as "Ale" or "Adarak," which is a significant crop due to its aromatic rhizomes and is used for medication. Ginger is used in dietary condiments in several forms like powdered, fresh, and dried. The taste of ginger is sharp and sweet with a pungent smell. The extract of ginger plays a vital role in restraining cold, cardiotonic influences, accumulation of platelets, gastrointestinal activities, thermogenic and antimicrobial actions (Guyer, 2003). Ginger comprises biologically active compounds such as gingerol, gingerol, and gingerdione. These biologically active compounds have anti-microbial activities, cardiotonic, hepatic-protective actions and accelerate the secretions of digestive enzymes, circulations of blood and display an enterokinetic effect when added to the diet of broilers (Dieumou et al., 2009; Incharoen and Yamauchi, 2009). Gingerol is responsible for the pungent taste of ginger (Thayalini et al., 2011; Jolad et al., 2004). "Zingibain" is the enzyme in ginger that is accountable for the assistance and improvement in the process of digestion (Adulyatham and Owusu-Apenten, 2005). Moreover, these bioactive components show a diversity of miraculous pharmacological, as well as physiological activities such as it hinders the synthesis of prostaglandins, leukotriene, and thromboxane (Bode and Dong, 2011; Guyer, 2003). The amount of these compounds may range from a few to many milligrams per gram of ginger (Bode and Dong, 2011). According to different studies, ginger has shown antioxidant, anti-microbial, antiinflammatory, anti-carcinogenic, anti-apoptotic, anti-parasitic, immune-stimulatory, hypo-lipidemic, anti-ulcer, and antihyperglycemic effects in poultry (Priya Rani et al., 2011; Onu, 2010; Rababah et al., 2004; Greathead, 2003; Mahady et al., 2003). Traditionally, ginger powder has been used to cure gastrointestinal (GIT) disorders as herbal medicine around the globe (Afzal et al., 2001).

Ginger has the natural potential to be used as a growth promoter and showed a good response as compared to artificial growth promoters like antibiotics (Demir et al., 2003). The addition of ginger powder in poultry feed helped in weight gain and performance while the reduction in cholesterol, triglyceride, and glucose (Mohamed et al., 2012). The extract of ginger plays a vital role in restraining cold, cardiotonic influences, accumulation of platelets, gastrointestinal activities, thermogenic and antimicrobial actions (Guyer, 2003). Several types of researches on animals and clinical studies on humans have shown promising results. Experimental trials on animals have revealed that ginger shows favorable outcomes in the metabolism of carbohydrates, lipids, and insulin sensitivity (Lindstedt, 2018). Furthermore, these facts have suggested the optimistic 
potential of ginger that cures kidneys, liver, and eyes of the diabetic organism (Lindstedt, 2018; Ali et al., 2008). Besides, ginger had been accountable to embellish the actions of digestive enzymes (Platel and Srinivasan, 2000).

The usage of ginger and ginger oil in broiler's diet enhanced antioxidant levels and blood serum high-density lipoproteins (HDL) (Rehman et al., 2016; Zhang et al., 2009). Moreover, Tag et al. (2015) stated that the ethanol extract of ginger causes a decrease in cholesterol level, triglycerides, increased HDL, tissue protection from peroxidation, and exhibits a substantial lipid reduction in diabetic rats. Mohamed et al. (2012) observed the ginger showed a convincing impact on overall growth in broilers. These herbal preparations are helpful in the digestion process and these natural preparations are supposed to be safe and sound, inexpensive in nature, as well as environment-friendly without any side effects. Hence their supplementation in the diet should be recommended to intensify the performance of birds, upgrade utilization of feed, the sustainability of health, and reduce the harmful act of environmental stress (Vinus et al., 2018). Therefore, this experiment was programmed to bring more information about using ginger at a different concentrations in poultry feeds to check their effect on growth performance, carcass characteristics, immunity, total bacterial count (TBC) and gut morphology in broilers.

\section{Materials and Methods}

A total of fifteen hundred, day-old broiler chicks of mixed sexes were procured from a local hatchery and brooded at $95^{\circ} \mathrm{F}$ for the first seven days and then decreased by $5^{\circ} \mathrm{F}$ every week until $75^{\circ} \mathrm{F}$ is achieved. The average weight of broiler chicks was about $46.05 \mathrm{~g}$. On day $1^{\text {st }}$, birds were distributed into 5 treatment groups ( $n=300$ chicks per group) in a complete randomized design as Positive control (PC), Negative control (NC), A, B, and C groups. Each treatment had six replicates (50 birds/ replicate) and acquired assorted supplementation feed during the experimental period of about (5 weeks). Clean, fresh drinking water having low TDS was provided to the birds round the clock. The birds were maintained in a house that had already fumigated and disinfected with formaldehyde. Continuous light was provided to chicks for the first two days and afterward, 23 hours of light and 1 hour of darkness was provided per day.

\subsection{Experimental design}

Five experimental diets were manufactured for starter (Table 1) and finisher phases (Table 2) for broiler birds. Dried ginger was procured from the local market and was ground with an electrical grinder to form a fine powder. The PC and NC groups were fed with a basal diet with or without antibiotics manufactured according to standards prescribed in the cobb manual, respectively (COBB, 2008). Group A, B, and C received a basal diet plus $3 \mathrm{~g} / \mathrm{kg}, 6 \mathrm{~g} / \mathrm{kg}$, and $9 \mathrm{~g} / \mathrm{kg}$ ginger, respectively. This research trial was performed according to the instructions of the National Institute of Health (NIH) for the care and use of laboratory animals and certified by the Committee of the Faculty of Animal Sciences, University of Veterinary and Animal

Table 1. Composition of experimental diet/feed formulation (starter diet \%).

\begin{tabular}{|c|c|c|c|c|c|}
\hline Ingredients & PC & NC & A & B & C \\
\hline MCP* & 0.3 & 0.3 & 0.3 & 0.3 & 0.3 \\
\hline Lysine HCL & 0.31 & 0.31 & 0.31 & 0.31 & 0.31 \\
\hline DLM $^{* *}$ & 0.263 & 0.263 & 0.263 & 0.263 & 0.263 \\
\hline Threonine & 0.1 & 0.1 & 0.1 & 0.1 & 0.1 \\
\hline Salt & 0.22 & 0.22 & 0.22 & 0.22 & 0.22 \\
\hline Soda & 0.1 & 0.1 & 0.1 & 0.1 & 0.1 \\
\hline Betain HCL & 0.075 & 0.075 & 0.075 & 0.075 & 0.075 \\
\hline Phytase & 0.010 & 0.010 & 0.010 & 0.010 & 0.010 \\
\hline Coxiril $\circledR^{* * *}$ & 0.01 & 0 & 0 & 0 & 0 \\
\hline Enramycine & 0.03 & 0 & 0 & 0 & 0 \\
\hline Vit Premix & 0.055 & 0.055 & 0.055 & 0.055 & 0.055 \\
\hline Min premix & 0.055 & 0.055 & 0.055 & 0.055 & 0.055 \\
\hline Trial product & 0.00 & 0.00 & 0.3 & 0.6 & 0.9 \\
\hline Rice polish & 0.272 & 0.272 & 0.272 & 0.272 & 0.272 \\
\hline Limestone & 1 & 1 & 1 & 1 & 1 \\
\hline Total & 2.8 & 2.8 & 2.8 & 2.8 & 2.8 \\
\hline \multicolumn{6}{|c|}{ Raw Material } \\
\hline Maize & 53.8 & 53.8 & 53.8 & 53.8 & 53.8 \\
\hline Soybean meal & 28 & 28 & 28 & 28 & 28 \\
\hline Canola meal & 4.4 & 4.4 & 4.4 & 4.4 & 4.4 \\
\hline $\mathrm{PBM}^{* * * *}$ & 3 & 3 & 3 & 3 & 3 \\
\hline Rice Polish & 8 & 8 & 8 & 8 & 8 \\
\hline
\end{tabular}

$\mathrm{PC}=$ positive control; $\mathrm{NC}=$ negative control; $\mathrm{A}=3 \mathrm{~g}$ ginger $/ \mathrm{kg}$ diet $; \mathrm{B}=6 \mathrm{~g}$ ginger $/ \mathrm{kg}$ diet $\mathrm{C}=9 \mathrm{~g}$ ginger $/ \mathrm{kg}$ diet; $\mathrm{MCP}$ = Mono-calcium phosphate; DLM $^{* *}=$ DL-methionine; Coxiril ${ }^{* * *}=$ Coccidiostat containing $0.5 \%$ Diclazuril as active ingredient; PMB ${ }^{* * * *}=$ Poultry by-products meal. 
Table 2. Composition of experimental diet/feed formulation (Finisher diet\%).

\begin{tabular}{|c|c|c|c|c|c|}
\hline Ingredients & PC & $\mathrm{NC}$ & A & B & C \\
\hline MCP* & 0.2 & 0.2 & 0.2 & 0.2 & 0.2 \\
\hline Lysine HCL & 0.33 & 0.33 & 0.33 & 0.33 & 0.33 \\
\hline $\mathrm{DLM}^{* *}$ & 0.22 & 0.22 & 0.22 & 0.22 & 0.22 \\
\hline Threo & 0.090 & 0.090 & 0.090 & 0.090 & 0.090 \\
\hline Salt & 0.22 & 0.22 & 0.22 & 0.22 & 0.22 \\
\hline Soda & 0.1 & 0.1 & 0.1 & 0.1 & 0.1 \\
\hline Betain HCL & 0.050 & 0.050 & 0.050 & 0.050 & 0.050 \\
\hline Phytase & 0.010 & 0.010 & 0.010 & 0.010 & 0.010 \\
\hline Coxiril $\circledR^{* * *}$ & 0.01 & 0 & 0 & 0 & 0 \\
\hline Enramycine & 0.03 & 0 & 0 & 0 & 0 \\
\hline Vit Premix & 0.055 & 0.055 & 0.055 & 0.055 & 0.055 \\
\hline Min premix & 0.055 & 0.055 & 0.055 & 0.055 & 0.055 \\
\hline Trial product & 0.00 & 0.00 & 0.3 & 0.6 & 0.9 \\
\hline Rice polish & 0.2 & 0.3 & 0.2 & 0.2 & 0.2 \\
\hline Limestone & 0.8 & 0.8 & 0.8 & 0.8 & 08 \\
\hline Total & 2.4 & 2.4 & 2.4 & 2.4 & 2.4 \\
\hline \multicolumn{6}{|c|}{ Raw Material } \\
\hline Maize & 63 & 63 & 63 & 63 & 63 \\
\hline Soybean meal & 25 & 25 & 25 & 25 & 25 \\
\hline Canola meal & 5 & 5 & 5 & 5 & 5 \\
\hline $\mathrm{PBM}^{* * * *}$ & 3 & 3 & 3 & 3 & 3 \\
\hline Rice Polish & 1.6 & 1.6 & 1.6 & 1.6 & 1.6 \\
\hline
\end{tabular}

$\mathrm{PC}=$ positive control $\mathrm{NC}=$ negative control $\mathrm{A}=3 \mathrm{~g}$ ginger $/ \mathrm{kg}$ diet $; \mathrm{B}=6 \mathrm{~g}$ ginger $/ \mathrm{kg}$ diet $; \mathrm{C}=9 \mathrm{~g}$ ginger $/ \mathrm{kg}$ diet $; \mathrm{MCP}^{*}=\mathrm{Mono}-\mathrm{calcium}$ phosphate $\mathrm{DLM}^{* *}=$ DL-methionine; Coxiril ${ }^{* * * *}=$ Coccidiostat containing $0.5 \%$ Diclazuril as active ingredient; PMB ${ }^{* * * *}=$ Poultry by-products meal.

Sciences, Lahore. The diets were manufactured according to NRC (1994), the composition of basal diets is illustrated in Tables 1,2 , and 3.

\subsection{Growth performance}

Growth performance parameters of the birds were measured on weekly basis (Badar et al., 2021). The body weight (BW) of birds from each replicate was measured after their arrival and at the last of each week. Data was noted on feed intake (FI) separately from each replicate. Consumed feed was computed by subtracting the refusal feed from the total feed offered during the week. BWG was calculated on weekly basis by subtracting of initial body weight from the final body weight. The weighing balance was used very consciously for this calculation. Besides, FCR was computed by dividing the feed consumed divided by BW of the birds.

\subsection{Carcass characteristics}

At the end of the rearing experiment, five birds were randomly selected from each replicate, individually weighted, and slaughtered. Afterward, carcass characteristics such as dressed, eviscerated and giblet weights were analyzed. After birds sacrificing, the
Table 3. Nutritional composition of basal diets used in this experiment.

\begin{tabular}{ccc}
\hline Ingredients & Starter Diet & Finisher Diet \\
\hline Dry matter (\%) & 88.5 & 88.6 \\
Crude protein (\%) & 23 & 21.5 \\
Ash (\%) & 5.0 & 4.0 \\
Crude fat (\%) & 4.0 & 4.5 \\
Crude fiber (\%) & 3.0 & 4.0 \\
ME (Kcal) & 2900 & 2950 \\
\hline
\end{tabular}

$\mathrm{ME}=$ metabolizable energy.

removal of feathers and blood is followed by the removal of visceral organs to obtain dressed, breast, and thigh meat weights. Eviscerated weight was calculated by evacuation of all internal organs except giblet organs. Giblet weight was calculated by weighing three internal organs (liver, heart, and gizzard) after slaughtering and expressed in percentage (Miya et al., 2019). Carcass weight is divided over live weight to obtain a dressing percentage (Badar et al., 2021). 


\subsection{Blood biochemistry}

Five birds per replicate were randomly taken for blood collection from the wing vein and placed these samples into non-heparinized tubes. These samples were centrifuged at 3000 RPM for 15 minutes to separate serum and kept in the freezer at $-20{ }^{\circ} \mathrm{C}$ until further use. Later on, serum was thawed at room temperature and analyzed under standard procedures and protocols by using commercially available laboratory kits; to determine serum triglycerides, HDL, low-density lipoproteins (LDL), and total cholesterol as described by Kamal and Ragaa (2014).

The concentration of triglycerides was analyzed by commercial laboratory kit (Triglycerides liquicolor mono $^{\circledR}$, Human $^{\mathrm{TM}}, 65205$ Wiesbaden Germany) and the concentration of total cholesterol was determined by laboratory kit (Cholesterol liqucolor ${ }^{\circledR,} \operatorname{Human}^{\mathrm{TM}}$, 65205 Wiesbaden, Germany) using ELISA. While, the concentrations of HDL were analyzed by analytical kit (HDL-Cholesterol $^{\circledR}$, Human $^{\mathrm{TM}}, 65205$ Wiesbaden, Germany) and LDL were analyzed by using an analytic kit (Direct LDL-Cholesterol SR ${ }^{\circledR}$, bioactive ${ }^{\mathrm{TM}}$, Bad Homburg, Germany).

\subsection{Hemagglutination inhibition (HI)}

Humoral immunity was estimated by using an antibody titer against the Newcastle disease virus (NDV) vaccine (Intervac NDV, Lasota strain, Snam Pharma Pvt Ltd). In this research trial, birds were vaccinated against NDV on day $1^{\text {st }}$; followed by day $7^{\text {th }}$ and $17^{\text {th }}$ through drinking water. Blood samples were taken from five birds per replicate at the $4^{\text {th }}$ week through the brachial vein puncture. While blood samples were also taken from birds on day $35^{\text {th }}$ through slaughtering for the determination of antibody titer. A three mL blood sample was taken in a non-heparinized vacutainer and placed in a cold chain. After thawing and centrifugation of samples at $3000 \mathrm{RPM}$ for 15 minutes at $23^{\circ} \mathrm{C}$, serum was separated and kept at $-20{ }^{\circ} \mathrm{C}$ for storage and further protocol. The NDV antibody titer was determined through commercial hem-agglutination inhibition (HI) based kit as prescribed by Aksu and Bozkurt (2009).

\subsection{Gut morphometry}

Gut morphology was evaluated on day $35^{\text {th }}$. For this purpose, tissue samples from the duodenum were taken from four birds per replicate. Tissue samples from the duodenum were cut about $3 \mathrm{~cm}$ from its central region. All the digesta present within them was removed and washed with distilled water. Then all these samples were preserved in neutral buffer formalin (10\%) for 48 hours. After that tissue samples were washed with running tap water and treated with the alcohol solution. Afterward, a proper section of tissues was cut and embedded in paraffin wax with the aid of cassettes. The sample tissue was cut down to four-micrometer sections with the aid of microtome, mounted on slides and stained with hematoxylin and eosin (H\&E) stain as described by Kokolakis et al. (2008). The light microscope was used for the examination of tissue sections and to estimate the villus height and crypt depths. The measurement from the apex (tip of the upper border) of villus till lamina propria was taken and recorded. Villus height and crypt depth were examined between crypts and villus according to the protocol as described by Panda et al. (2009).

\subsection{Caecal microbiota}

Caecal microbiota was calculated from four birds per replicate. For this purpose, the caeca (blind pouches) were separated post slaughtering and placed in $0.9 \% \mathrm{NaCl}$ solution after eliminating the digesta. A 10 -fold dilution was used to calculate total bacterial count (TBC); in which 1-mL of each dilution was inoculated on nutrient agar (1.05450.0500) plates by spread plate method. Nutrient agar media was used to culture the bacterial colonies. The total bacterial count was done bestowing the protocol endorsed by Hartemink and Rombouts (1999). After agitation for 30 mints, $1 \mathrm{~mL}$ samples of the suspensions was added into $9 \mathrm{~mL}$ PBS for serial dilution at $10^{-2}, 10^{-3}$, $10^{-4}, 10^{-5}, 10^{-6}$, then, $100 \mu \mathrm{L}$ was discarded from $10^{-4}$, $10^{-5}$, and $10^{-6}$ dilutions and added to Petri dishes, which were incubated under anaerobic conditions at $37{ }^{\circ} \mathrm{C}$ for 72 hours. After incubation, total colony forming units (CFU) of different bacterial species were counted for the determination of total intestinal bacteria using a method recommended by Hartemink and Rombouts (1999). Bacterial units were counted by a colony counter and adjusted to a $1 \mathrm{~g}$ sample. Then that bacterial population was taken as $\log _{10}$ CFU/gram.

\subsection{Statistical analysis}

Analyses of data were carried out by using general linear model procedures of SPSS version 21.0 software (SPSS Inc., Chicago, IL, USA). The difference between means was compared by using Duncan's multiple range test. The level of significance was set at $(\mathrm{p}<0.05)$. The geometric mean (G.M) of the estimated Hemagglutination inhibition (HI) titers was calculated according to Brugh Junior (1978).

\section{Results}

\subsection{Growth performance}

The influence of dietary supplementation of Zingiber officinale at the level of $3 \mathrm{~g} / \mathrm{kg}, 6 \mathrm{~g} / \mathrm{kg}$, and $9 \mathrm{~g} / \mathrm{kg}$ diet on broiler growth performance during this research trial was illustrated in Table 4 . The present study showed a significant difference $(\mathrm{p}<0.05)$ in FI among different groups. Groups $\mathrm{C}$ showed the highest $(3449 \pm 28.12 \mathrm{~g}$ ) while the NC group showed the lowest $(3308 \pm 14.63 \mathrm{~g})$ FI among different groups. The results of the final BWG were significantly different within the treatment $(p<0.05)$. The mean highest BWG was observed in group B while it was lowest in the NC group. The FCR showed a significant difference among the supplemented groups. A better FCR was observed in group B as compared to the other supplemented groups. Group $\mathrm{C}$ which was fed with the highest concentration level of Zingiber officinale, observed an increase in FCR.

\subsection{Carcass characteristics}

The effect of supplementation of Zingiber officinale on carcass characteristics is shown in Table 5. Group "B" 
Table 4. Effect of dietary supplementation of Zingiber officinale on feed intake (FI), body weight gain (BWG) and feed Conversion Ratio (FCR) (0 to $35^{\text {th }}$ day).

\begin{tabular}{ccccc}
\hline \multirow{2}{*}{ Group } & \multicolumn{4}{c}{ Parameters } \\
\cline { 2 - 5 } & Treatment & FI (g) & BWG (g) & FCR \\
\hline PC & Positive control group (basal diet plus antibiotics) & $3319^{\mathrm{b}} \pm 6.32$ & $2054^{\mathrm{c}} \pm 23.71$ & $1.62^{\mathrm{a}} \pm 0.02$ \\
NC & Negative control group (basal diet without antibiotics) & $3308^{\mathrm{b}} \pm 14.63$ & $2024^{\mathrm{c}} \pm 22.81$ & $1.64^{\mathrm{a}} \pm 0.02$ \\
A & Basal diet plus dried Ginger root powder @0.3\% & $3329^{\mathrm{b}} \pm 11.21$ & $2164^{\mathrm{b}} \pm 10.36$ & $1.54^{\mathrm{b}} \pm 0.01$ \\
B & Basal diet plus dried Ginger root powder @0.6\% & $3292^{\mathrm{b}} \pm 12.75$ & $2249^{\mathrm{a}} \pm 6.36$ & $1.46^{\mathrm{c}} \pm 0.01$ \\
C & Basal diet plus dried Ginger root powder @0.8\% & $3449^{\mathrm{a}} \pm 28.12$ & $2092^{\mathrm{bc}} \pm 16.65$ & $1.65^{\mathrm{a}} \pm 0.02$ \\
& $\boldsymbol{P}$-value & $\mathbf{0 . 0 0 1}$ & $\mathbf{0 . 0 0 1}$ & $\mathbf{0 . 0 0 1}$ \\
\hline
\end{tabular}

a,b,c Means with different superscripts within a column are significantly different $(\mathrm{P}<0.05)$. Feed intake (FI), Body weight gain (BWG) and Feed Conversion Ratio (FCR).

Table 5. Effect of dietary supplementation of Zingiber officinale on carcass characteristics of broilers.

\begin{tabular}{ccccc}
\hline \multirow{2}{*}{ Groups } & \multicolumn{4}{c}{ Parameters } \\
\cline { 2 - 5 } & Live weight (g) & Eviscerated weight (g) & Dressing (\%) & Giblet (\%) \\
\hline Positive control & $2003 \pm 14.6$ & $1346 \pm 15.5$ & $63.2 \pm 0.9$ & $5.4 \pm 3.7$ \\
Negative control & $1972 \pm 14.7$ & $1396 \pm 30.4$ & $62.4 \pm 1.3$ & $6.1 \pm 2.7$ \\
Group A (0.3\% ginger) & $2023 \pm 14.5$ & $1386 \pm 12.1$ & $64.1 \pm 0.6$ & $5.5 \pm 2.9$ \\
Group B (0.6\% ginger) & $2019 \pm 13.6$ & $1349 \pm 10.2$ & $66.2 \pm 0.3$ & $5.7 \pm 4.3$ \\
Group C (0.9\% ginger) & $1993 \pm 11.5$ & $1374 \pm 20.3$ & $64.7 \pm 0.8$ & $5.8 \pm 1.7$ \\
P-value & 0.064 & 0.282 & 0.040 & 0.088 \\
\hline
\end{tabular}

Table 6. Effect of dietary supplementation of Zingiber officinale on Serum Biochemistry of broilers.

\begin{tabular}{ccccc}
\hline \multirow{2}{*}{ Groups } & \multicolumn{4}{c}{ Parameters } \\
\cline { 2 - 5 } & Cholesterol (mg/dl) & Triglycerides (mg/dl) & HDL (mg/dl) & LDL (mg/dl) \\
\hline Positive control & $207.95 \pm 1.35^{\mathrm{ab}}$ & $209.48 \pm 1.67^{\mathrm{a}}$ & $46.40 \pm 0.97^{\mathrm{ab}}$ & $110.19 \pm 0.27^{\mathrm{a}}$ \\
Negative control & $213.41 \pm 1.61^{\mathrm{a}}$ & $211.31 \pm 2.25^{\mathrm{a}}$ & $38.50 \pm 1.80^{\mathrm{c}}$ & $108.70 \pm 0.60^{\mathrm{a}}$ \\
Group A (0.3\% ginger) & $205.31 \pm 1.22^{\mathrm{b}}$ & $202.73 \pm 1.58^{\mathrm{b}}$ & $50.50 \pm 3.96^{\mathrm{a}}$ & $106.65 \pm 0.27^{\mathrm{b}}$ \\
Group B (0.6\% ginger) & $196.55 \pm 1.24^{\mathrm{c}}$ & $194.49 \pm 0.96^{\mathrm{c}}$ & $47.17 \pm 2.00^{\mathrm{b}}$ & $104.43 \pm 0.49^{\mathrm{c}}$ \\
Group C (0.9\% ginger) & $197.02 \pm 1.43^{\mathrm{c}}$ & $194.96 \pm 1.35^{\mathrm{c}}$ & $42.00 \pm 2.32^{\mathrm{ab}}$ & $105.86 \pm 0.47^{\mathrm{bc}}$ \\
P-value & 0.008 & 0.001 & 0.016 & 0.001 \\
\hline
\end{tabular}

a,b,c,Means with different superscripts within a column are significantly different $(\mathrm{P}<0.05)$. HDL $=$ High density lipoprotein; $\mathrm{LDL}=\mathrm{Low}$ density lipoprotein.

containing ginger powder $0.6 \%$ manifested the highest dressing percentage followed by group $\mathrm{C}$ having ginger powder $0.9 \%$, while it was lowest for NC group. The NC group showed the highest while group A showed the lowest giblet weight percentage.

\subsection{Blood biochemistry}

The influence of dietary supplementation of Zingiber officinale on blood biochemistry of broilers is shown in Table 6. Group B showed a significant $(\mathrm{P}<0.05)$ decrease in blood cholesterol and triglycerides as compared to PC and NC groups. The blood HDL level was highest in group $\mathrm{A}(50.50 \pm 3.96 \mathrm{mg} / \mathrm{dl})$ and lowest in NC group (38.50 $\pm 1.80 \mathrm{mg} / \mathrm{dl}$ ). The level of LDL was significantly $(\mathrm{p}<0.05)$ decreased in Group B followed by group $\mathrm{C}$ than other groups.

\subsection{Hemagglutination inhibition (HI)}

The effect of dietary supplementation of Zingiber officinale on the immune response of broilers is shown in Table 7. On the $28^{\text {th }}$ day the group B showed the highest $(9.67 \pm 0.42)$ antibody titer against NDV while it was lowest $(2.83 \pm 0.40)$ in NC group. However, on the $35^{\text {th }}$ day, there was a non-significant $(\mathrm{p}<0.05)$ difference in antibody titer against NDV among different groups while numerically it was still highest $(5.17 \pm 0.79)$ in group $B$. 


\subsection{Total bacterial count (TBC)}

The effect of dietary supplementation of Zingiber officinale on TBC of broilers is shown in Table 8. The Zingiber officinale supplementation to the broiler feeds significantly $(\mathrm{p}<0.05)$ reduced the TBC. The lower bacterial count was observed in group $\mathrm{C}(7.65 \mathrm{CFU} / \mathrm{g})$ followed by group B (7.75 CFU/g) while it was highest in NC group (8.48 CFU/g).

\subsection{Gut morphometry}

The effect of dietary supplementation of Zingiber officinale on the gut morphology of broilers is shown in Table 9 and Figure 1. Group B showed significantly ( $p<0.05)$ highest villi length $(905.30 \pm 44.98$ um $)$, villi width (95.82 $\pm 1.80 \mathrm{um})$ and crypt depth (126.52 $\pm 1.71 \mathrm{um})$ than other groups. While the PC group showed significantly $(\mathrm{p}<0.05)$ lowest villi length $(714.50 \pm 1.06 \mathrm{um})$, villi width

Table 7. Effect of dietary supplementation of Zingiber officinale on immune response of broilers.

\begin{tabular}{ccc}
\hline \multirow{2}{*}{ Groups } & \multicolumn{2}{c}{ Parameters } \\
\cline { 2 - 3 } & $\begin{array}{c}\text { ND titer } \\
\left(\text { day 28 } \mathbf{8}^{\text {th }}\right)\end{array}$ & $\begin{array}{c}\text { ND titer } \\
\left(\text { day 35 }^{\text {th }}\right)\end{array}$ \\
\hline Positive control & $2.83 \pm 0.40^{\mathrm{c}}$ & $4.50 \pm 1.02$ \\
Negative control & $3.50 \pm 0.56^{\mathrm{c}}$ & $4.50 \pm 0.85$ \\
Group A (0.3\% ginger) & $3.83 \pm 0.70^{\mathrm{bc}}$ & $4.33 \pm 0.92$ \\
Group B (0.6\% ginger) & $9.67 \pm 0.42^{\mathrm{a}}$ & $5.17 \pm 0.79$ \\
Group C (0.9\% ginger) & $6.17 \pm 0.70^{\mathrm{b}}$ & $4.00 \pm 0.86$ \\
P-value & 0.001 & 0.921 \\
\hline
\end{tabular}

a.b,c,Means with different superscripts within a column are significantly different $(P<0.05)$. $\log _{2}$ value of ND HI titer. ND = Newcastle disease.
Table 8. Effect of dietary supplementation of Zingiber officinale on Total Bacterial Count (TBC) of broilers.

\begin{tabular}{cc}
\hline Groups & Total bacterial count \\
\hline Positive control & $8.07^{\mathrm{b}}$ \\
Negative control & $8.48^{\mathrm{a}}$ \\
Group A (0.3\% ginger) & $7.92^{\mathrm{b}}$ \\
Group B (0.6\% ginger) & $7.75^{\mathrm{c}}$ \\
Group C (0.9\% ginger) & $7.65^{\mathrm{c}}$ \\
P-value & 0.001 \\
\hline
\end{tabular}

(Log $10 \mathrm{CFU} / \mathrm{g}$ ): colony forming unit. a,b,c,Means with different superscripts within a column are significantly different $(\mathrm{P}<0.05)$.

Table 9. Effect of dietary supplementation of Zingiber officinale on gut morphology in broilers.

\begin{tabular}{|c|c|c|c|}
\hline \multirow[b]{2}{*}{ Groups } & \multicolumn{3}{|c|}{ Parameters } \\
\hline & $\begin{array}{c}\text { Villi length } \\
(\mu \mathrm{m})\end{array}$ & $\begin{array}{l}\text { Villi width } \\
\quad(\mu \mathrm{m})\end{array}$ & $\begin{array}{l}\text { Crypt depth } \\
(\mu \mathrm{m})\end{array}$ \\
\hline $\begin{array}{l}\text { Positive } \\
\text { control }\end{array}$ & $714.50 \pm 1.06^{\mathrm{b}}$ & $61.19 \pm 1.96^{b}$ & $63.05 \pm 2.73^{c}$ \\
\hline $\begin{array}{l}\text { Negative } \\
\text { control }\end{array}$ & $756.00 \pm 31.46^{b}$ & $89.86 \pm 7.39^{a}$ & $92.87 \pm 11.05^{a b c}$ \\
\hline $\begin{array}{l}\text { Group } \\
\mathrm{A}(0.3 \% \\
\text { ginger })\end{array}$ & $885.50 \pm 18.04^{a}$ & $93.22 \pm 3.50^{\mathrm{a}}$ & $115.07 \pm 1.59^{\mathrm{ab}}$ \\
\hline Group & & & \\
\hline $\begin{array}{l}\mathrm{B}(0.6 \% \\
\text { ginger })\end{array}$ & $905.30 \pm 44.98^{a}$ & $95.82 \pm 1.80^{\mathrm{a}}$ & $126.52 \pm 1.71^{\mathrm{a}}$ \\
\hline Group & & & \\
\hline $\begin{array}{l}\mathrm{C}(0.9 \% \\
\text { ginger })\end{array}$ & $895.10 \pm 1.14^{a}$ & $83.88 \pm 4.56^{\mathrm{ab}}$ & $88.27 \pm 4.92^{\mathrm{bc}}$ \\
\hline P-value & 0.010 & 0.017 & 0.02 \\
\hline
\end{tabular}
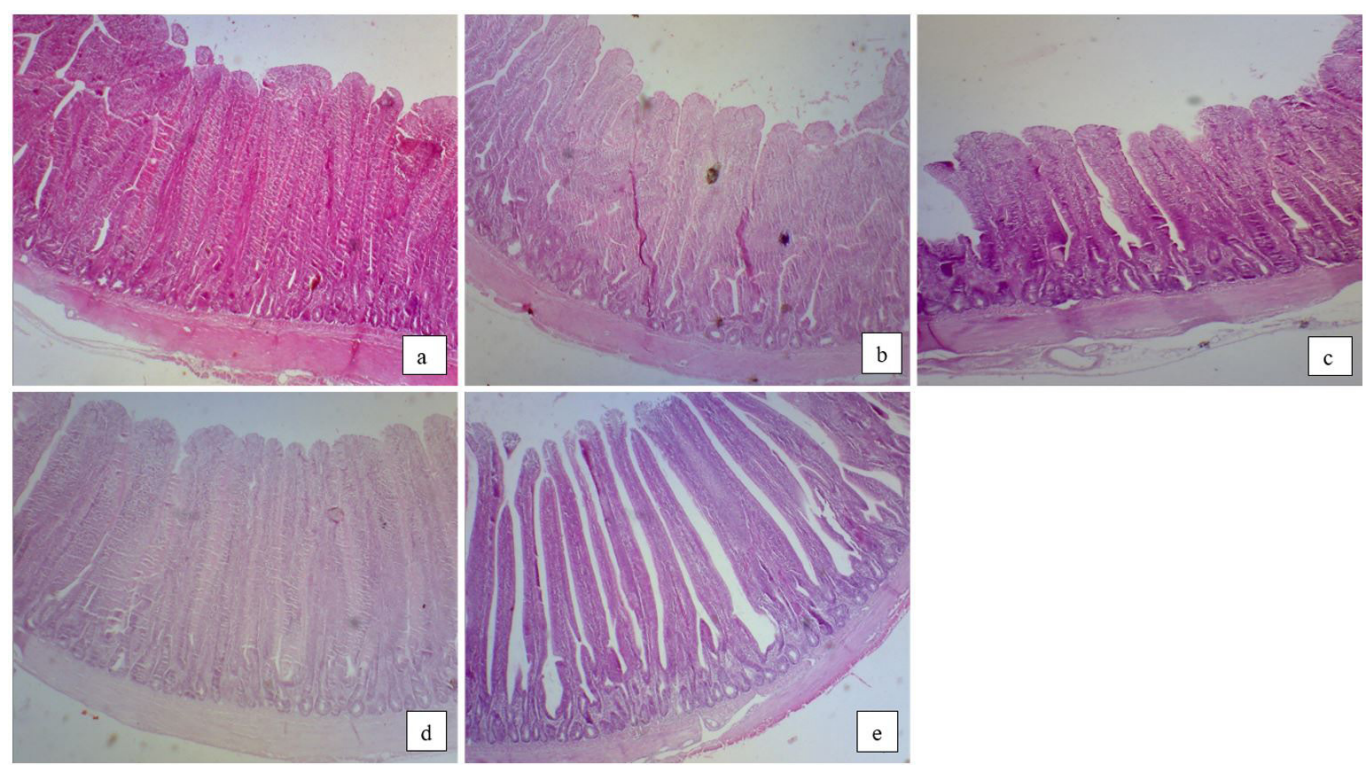

Figure 1. Illustrative picture of the Duodenum mucosa, sub-mucosa of Positive, negative controls, and dietary ginger-supplemented broilers, stained with HE, Bar: $100 \mu \mathrm{m}$ : (a) Positive control (basal diet plus antibiotics); (b) Negative control (basal diet without antibiotics); (c) Basal diet supplemented with $3 \mathrm{~g} / \mathrm{kg}$ ginger; (d) Basal diet supplemented with $6 \mathrm{~g} / \mathrm{kg}$ ginger; and (e) Basal diet supplemented with $9 \mathrm{~g} / \mathrm{kg}$ grounded form of ginger. Examination with the aid of a light microscope had shown normal histological images of the intestinal villi and their crypts, tunica muscularis, and submucosa of the duodenum. 
(61.19 $\pm 1.96 \mathrm{um})$ and crypt depth $(63.05 \pm 2.73 \mathrm{um})$ among all groups.

\section{Discussion}

The growth performance, blood biochemistry, immunological response, gut morphometry, and slaughter traits of broiler were analyzed in this study. This experiment manifested that ginger supplementation @6 g/ $/ \mathrm{kg}$ resulted in higher BWG, lower FI and FCR than other groups. Whereas, ginger supplementation @9 g/kg lower BWG, higher FI and FCR as compared to the other groups. Different studies reported higher BWG of broilers supplemented with ginger @20 g/kg in diet (Ademola et al., 2009; Onimisi et al., 2005). However, Herawati and Marjuki (2011) reported a remarkable decline in BWG by feeding ginger powder up to $20 \mathrm{~g} / \mathrm{kg}$ to the broiler feed. Whereas, Zhang et al. (2009) observed no effect on growth performance by feeding ginger @ $5 \mathrm{~g} / \mathrm{kg}$ to the broilers. It was shown that there was no adverse effect of odour of ginger powder supplementation on the FI intake of broilers. Similar to our study, Karangiya et al. (2016) reported a higher FI in $10 \mathrm{~g} / \mathrm{kg}$ ginger powder supplemented groups than control groups ( $3367 \mathrm{~g}$ vs $3270 \mathrm{~g}$ ). In another study, Valiollahi et al. (2014) also reported that supplementation of $10 \mathrm{~g} / \mathrm{kg}$ ginger powder and $10 \mathrm{~g} / \mathrm{kg}$ black poepper mixture to broiler ration resulted in higher FI (3831 g vs $3767 \mathrm{~g}$ ) than the control group. However, contrary, Eltazi (2014) reported decrease in feed intake by feeding the ginger power @20 g/ $\mathrm{kg}$ in the broiler feed. Supplementation of ginger powder @9 g/kg didn't affect the FCR as compared to the control groups. However, ginger supplementation @3 g/kg and @6 g/kg showed better FCR than other groups. Similarly, Mohamed et al. (2012) reported improved FCR in the 0.1\% and $0.2 \%$ ginger supplemented groups. The improved FCR in groups A and B may be due to stimulation of gastric and salivary gland secretions consequently resulting in the decreased microbial count and improved digestive activities of the gut of birds (Greathead, 2003; Incharoen and Yamauchi, 2009). However, (Ademola et al., 2009; Thayalini et al., 2011) did not report an improvement in the FCR of broilers fed with ginger supplemented feed than control groups.

Regarding the carcass charcteristics, there were a nonsignificant difference in the eviscerated weight, dressing and giblet percentages among different treatment groups. However, numerically NC, B and C groups showed the highest eviscerated weight, dressing and giblet percentages respectively than other groups. Similarly, Barazesh et al. (2013) reported that the addition of ginger at different concentrations did not affect carcass characteristics. However, Ahmad (2011) observed that the addition of $2 \%$ garlic and $1 \%$ Zingiber officinale mixture resulted in an improved average dressing percentage (71 vs 68) as compared to the control group. Similarly, Eltazi (2014) reported that the inclusion of ginger at $1 \%$ in broiler ration positively affected hot dressing percentage (70 vs 68) and cold dressing percentage (69 vs 68 ) than the control group. On the other hand, Fakhim et al. (2013) reported supplementation of ginger extract at $0.75 \%$ in dietary water of broilers improved carcass yield \%, however, no differences were reported in the weights of liver, abdominal fat and gut than the control group.

This study revealed a remarkable reduction in the serum cholesterol, as well as triglycerides in the broilers in comparison with control. The lowest cholesterol and triglycerides were reported in B group than control groups. Whereas, the serum HDL was raised in groups A and B than control groups. The serum LDL was declined in the ginger powder supplemented groups than the control groups. Rehman and Haq (2014) found similar results and conclude that the addition of ginger $2 \%$ along with garlic $1 \%$ in the feed of broilers raised the serum HDL level and declined the level of LDL, total cholesterol as well as triglycerides in the blood of broilers. Our results are also inconsistent with Qorbanpour et al. (2018) having reduced LDL level by the addition of ginger at the proportion of $25 \mathrm{~g} / \mathrm{kg}$. However, the authors, reported that the total cholesterol, protein, albumin and globulin were un-affected by ginger supplementation. Similarly, Mohamed et al. (2012) reported a decrease in total cholesterol, triglycerides and glucose level by feeding ginger at the proportion of $0.2 \%$ to the broiler birds. However, in contrast, Barazesh et al. (2013) reported no difference in the cholesterol, HDL, triglycerides and LDL among the ginger supplemented and control group, however, blood glucose level was decreased in the control group. This hypolipidemic effect of ginger on the broilers was also observed by Ademola et al. (2009). The authors reported decreased triglycerides and total cholesterol in ginger-treated groups. The mechanism behind this hypolipidemic effect might be due to the presence of HMG-COA (hydroxyl methyl glutaryl coenzyme A reductase) in the ginger. Futhermore the inclined excretion of cholesterol or bile acids in the feces of broilers could also exert a hypolipidemic effect (Malekizadeh et al. 2012). Another possible reason for the reduction of cholesterol as well as LDL by the addition of ginger in the feed might be due to the reduction of a specific enzyme named hepatic phosphorylase which enhanced the breakdown of liver glycogen reserves. Ginger might also cause the stimulation of exercise of different glycogenic enzymes, which ultimately lead to reduced blood cholesterol levels (Zhang and Tan, 2000).

Usually, the herbal extracts in the broiler feed improve the immune response. In this study, the addition of various concentrations of ginger in the broilers diet raised the antibody titer in the blood against Newcastle disease on the $28^{\text {th }}$ day of age. Similarly, Azhir et al. (2012) and Nidaullah et al. (2010) reported the boosting the effect of ginger supplementation on the immune system of broilers. However, George et al. (2015) reported that the immune system and other blood parameters including white blood cells (WBC), red blood cells (RBC), packed cell volume (PCV) and hemoglobin $(\mathrm{Hb})$ remained unaffected by feed the ginger extract @0.2, 0.4 and 0.6\% to the broilers. However, Toghyani et al. (2011) reported no positive impact on the immune system against NDV in broilers due to the dietary addition of ginger in the feed. The reason behind the immunity-boosting effect of ginger might be due to the anti-oxidation effects as well as natural aromatic active constituents such as gingerol 
and shogoals (Khan et al., 2012). Ali et al. (2008) also noticed that certain anti-inflammatory and anti-oxidation activity containing components were found in ginger which indirectly enhanced the birds' immunity.

Different herbal extracts have shown a positive impact on the gut morphometry of broilers. In the current study, an increase in villus length, as well as width and crypt depth was observed when different levels of ginger were included in the broilers' diet. Similarly, Karangiya et al. (2016) reported a significant difference improvement in the villus height and crypt depth than the control group. Shewita and Taha (2018) also reported similar findings related to the villus length. This rise in villi length along with width caused the increase in the surface area for the absorption of different nutrients which ultimately results in an improvement in the growth and overall performance of the birds (Oladele et al., 2012). Bowen (2011) reported that the crypts cells are responsible for the electrolyte production through the excretory activity of crypt cells into the intestinal lumen which ultimately boosts up the digestive activities of the gut.

Herbal extracts and products are helpful in decreasing the bacterial count in the intestine of the broilers. This study also manifested the lowering effect on the microbial count in the caecum of the broiler birds. Similarly, Vinus et al. (2018) and Ekwenye and Elegalam (2005) also reported that lowering effect of ginger supplementation in broiler ration on caecal bacterial count than the control group. A decrease count of Escherichia coli in the broilers fed with ginger might be due to the presence of gingerdione as an active component that has special antibacterial activity (Qorbanpour et al., 2018). Rawat (2015) observed a significant increase in the beneficial bacteria like Lactobacilli and decreased pathogenic bacteria (gram-negative) like E.coli in the gut of broilers. Different pathogenic bacteria outbreaks were reduced by the feeding of herbal extracts like Aloe vera, ginger, Moringaolifera, and garlic in the diet of broilers. This decreased risk of outbreaks was due to the anti-microbial properties of certain phytogenic diet additives (Alloui et al., 2014).

\section{Conclusion}

In conclusion, dried ginger could be effectively used as an alternative to antibiotics in broiler feed. No detrimental or controversial impacts were observed on bird health due to ginger supplementation in the broiler diet. The ginger supplementation @6 g/kg reported the best growth performance and gut health. Whereas, the immune system, triglycerides and cholesterol level showed improvement in @9 g/kg ginger supplemented group that might be due to high anti-oxidant effect of ginger. Concisely, the ginger supplenetation @6 g/ kg in the broiler diet could be used as a remarkable growth promoter and better natural alternative to antibiotics. However, further research is needed to explore the effect of ginger supplementation in broiler feed at higher concentrations.

\section{Acknowledgements}

We gratefully acknowledge Sultan Poultry Feeds, ShapurSadhar Sargodha for supporting us in conducting this research. Especially thanks to Dr. Muhammad Asad Iqbal (General Manager Sultan Poultry feed) and Dr. Muhammad Jhanzaib (Assistant Production Manager Sultan Poultry feeds) for providing financial support and facilities during this experimental trial.

\section{References}

ADEMOLA, S., FARINU, G. and BABATUNDE, G., 2009. Serum lipid, growth and haematological parameters of broilers fed garlic, ginger and their mixtures. World Journal of Agricultural Sciences, vol. 5, no. 1, pp. 99-104.

ADULYATHAM, P. and OWUSU-APENTEN, R., 2005. Stabilization and partial purification of a protease from ginger rhizome (Zingiber offinale Roscoe). Journal of Food Science, vol. 70, no. 3, pp. C231-C234. http://dx.doi.org/10.1111/j.1365-2621.2005. tb07130.x.

AFZAL, M., AL-HADIDI, D., MENON, M., PESEK, J. and DHAMI, M., 2001. Ginger: an ethnomedical, chemical and pharmacological review. Drug Metabolism and Drug Interactions, vol. 18, no. 3-4, pp. 159-190. http://dx.doi.org/10.1515/DMDI.2001.18.3-4.159. PMid:11791883.

AHMAD, B., 2011. Response of broiler chickens to garlic and ginger supplementation. Faisalabad: Department of Poultry Science, University of Agriculture. M.Sc. Thesis in Poultry Nutrition.

AKSU, T. and BOZKURT, A.S., 2009. Effect of dietary essential oils and/or humic acids on broiler performance, microbial population of intestinal content and antibody titres in the summer season. Kafkas Üniversitesi Veteriner Fakültesi Dergisi, vol. 15, no. 2, pp. 185-190.

ALI, B.H., BLUNDEN, G., TANIRA, M.O. and NEMMAR, A., 2008. Some phytochemical, pharmacological and toxicological properties of ginger (Zingiber officinale Roscoe). a review of recent research. Food and Chemical Toxicology, vol. 46, no. 2, pp. 409-420. http:// dx.doi.org/10.1016/j.fct.2007.09.085. PMid:17950516.

ALLOUI, I.M., AGABOU, A. and ALLOUI, N., 2014. Application of herbs and phytogenic feed additives in poultry production: a review. Global Journal of Animal Scientific Research, vol. 2, no. 3, pp. 234-243.

AZHIR, D., ZAKERI, A. and KARGARE-REZAPOUR, A., 2012. Effect of ginger powder rhizome on homural immunity of broiler chickens. European Journal of Experimental Biology, vol. 2, no. 6, pp. 2090-2092.

BADAR, I., JASPAL, M., YAR, M., IJAZ, M., KHALIQUE, A., ZHANG, L., MANZOOR, A., ALI, S., RAHMAN, A. and HUSNAIN, F., 2021. Effect of strain and slaughter age on production performance, meat quality and processing characteristics of broilers reared under tropical climatic conditions. Archiv für Geflügelkunde, vol. 85, pp. 1-17.

BARAZESH, H., POUR, M.B., SALARI, S. and ABADI, T.M., 2013. The effect of ginger powder on performance, carcass characteristics and blood parameters of broilers. International Journal of Advanced Biological and Biomedical Research, vol. 1, no. 12, pp. $1645-1651$.

BAYRAM, İ., ÇETINGÜL, I.S., YARDIMCI, M., ŞAHIN, E.H., AKKAYA, A.B. and UYARLAR, C., 2008. Effects of poppy seed oil supplementation in diets on egg production, egg quality and some blood parameters in laying hens. Kocatepe Veteriner Dergisi, vol. 1, no. 1, pp. 37-42. 
BAYRAM, I., CETINGUL, I.S., AKKAYA, B. and UYARLAR, C., 2007. Effects of Aniseed (Pimpinella anisum L.), on egg production, quality, cholesterol levels, hatching results and the antibody values in blood of laying quails (Coturnix coturnix japonica). Archiva Zootechnica, vol. 10, pp. 73-77.

BODE, A.M. and DONG, Z., 2011. The amazing and mighty ginger. In: I.F.F. BENZIE and S. WACHTEL-GALOR, eds. Herbal medicine: biomolecular and clinical aspects. 2nd ed. Boca Raton: Taylor \& Francis.

BOWEN, R., 2011. Villi, crypts and the life cycle of small intestinal enterocytes. Fort Collins: Colorado State University.

BRUGH JUNIOR, M., 1978. A simple method for recording and analyzing serological data. Avian Diseases, vol. 22, no. 2, pp. 362-365. http://dx.doi.org/10.2307/1589552. PMid:678239.

CHRUBASIK, S., PITTLER, M.H. and ROUFOGALIS, B.D., 2005. Zingiberis rhizoma: a comprehensive review on the ginger effect and efficacy profiles. Phytomedicine, vol. 12, no. 9, pp. 684-701. http://dx.doi.org/10.1016/j.phymed.2004.07.009. PMid: 16194058

COBB, 2008. Cobb 500: suplemento de crescimento e nutrição para frangos de corte. São Paulo: Cobb-Vantress Brasil.

COSBY, D.E., COX, N.A., HARRISON, M.A., WILSON, J.L., BUHR, R.J. and FEDORKA-CRAY, P.J., 2015. Salmonella and antimicrobial resistance in broilers: a review. Journal of Applied Poultry Research, vol. 24, no. 3, pp. 408-426. http://dx.doi.org/10.3382/ japr/pfv038.

CROSS, D.E., MCDEVITT, R.M., HILLMAN, K. and ACAMOVIC, T., 2007. The effect of herbs and their associated essential oils on performance, dietary digestibility and gut microflora in chickens from 7 to 28 days of age. British Poultry Science, vol. 48, no. 4 , pp. 496-506. http://dx.doi.org/10.1080/00071660701463221. PMid:17701503.

DEMIR, E., SARICA, Ş., ÖZCAN, M.A. and SUI MEZ, M., 2003. The use of natural feed additives as alternatives for an antibiotic growth promoter in broiler diets. British Poultry Science, vol. 44, no. S1, pp. 44-45. http://dx.doi.org/10.1080/713655288.

DEVEGOWDA, G., 1996. Herbal medicines, an untapped treasure in poultry production. In: Proceedings of the 20th World Poultry Congress, 1996, New Delhi, India. The Netherlands: WPSA.

DIEUMOU, F.E., TEGUIA, A., KUIATE, J.R., TAMOKOU, J.D., FONGE, N.B. and DONGMO, M.C., 2009. Effects of ginger (Zingiber officinale) and garlic (Allium sativum) essential oils on growth performance and gut microbial population of broiler chickens. Livestock Research for Rural Development, vol. 21, no. 8, pp. 23-32.

EKWENYE, U. and ELEGALAM, N., 2005. Antibacterial activity of ginger (Zingiber officinale Roscoe) and garlic (Allium sativum L.) extracts on Escherichia coli and Salmonella typhi. International Journal of Molecular Sciences, vol. 1, pp. 411-416.

ELTAZI, S., 2014. Response of broiler chicks to diets containing different mixture levels of garlic and ginger powder as natural feed additives. International Journal of Pharmaceutical Research E'Allied Sciences, vol. 3, no. 4, pp. 27-35.

FAKHIM, R., EBRAHIMNEZHAD, Y., SEYEDABADI, H.R. and VAHDATPOUR, T., 2013. Effect of different concentrations of aqueous extract of ginger (Zingiber officinale) on performance and carcass characteristics of male broiler chickens in wheatsoybean meal based diets. Journal of BioScience and Biotechnology, vol. 2, no. 2, pp. 95-99.

GEORGE, O.S., KAEGON, S.G. and IGBOKWE, A.A., 2015. Feed additive effects of graded levels of ginger (Zingiber Officinale) on serum metabolites of broilers. Journal of Agriculture and Veterinary Science, vol. 8, pp. 59-62.
GHAZALAH, A.A. and ALI, A.M., 2008. Rosemary leaves as a dietary supplement for growth in broiler chickens. International Journal of Poultry Science, vol. 7, no. 3, pp. 234-239. http://dx.doi. org/10.3923/ijps.2008.234.239.

GREATHEAD, H., 2003. Plants and plant extracts for improving animal productivity. Proceedings of the of the Nutrition Society, vol. 62, no. 2, pp. 279-290. http://dx.doi.org/10.1079/PNS2002197.

GUYER, D., 2003 [viewed 26 June 2019]. Advanced medical centre Zionsville, Indiana, Indianapolis, USA. Zionsville, IN: Advanced Medical Centre. Available from: http://www;daleguyermd. com/glosary. /ginger. htlm.

HARTEMINK, R. and ROMBOUTS, F.M., 1999. Comparison of media for the detection of bifidobacteria, lactobacilli and total anaerobes from faecal samples. Journal of Microbiological Methods, vol. 36, no. 3, pp. 181-192. http://dx.doi.org/10.1016/ S0167-7012(99)00031-7. PMid:10379804.

HERAWATI, M. and MARJUKI., 2011. The effect of feeding red ginger (Zingiber officinale rosc) as phytobiotic on broiler slaughter weight and meat quality. International Journal of Poultry Science, vol. 10, no. 12, pp.983-985. http://dx.doi.org/10.3923/ ijps.2011.983.986.

INCHAROEN, T. and YAMAUCHI, K., 2009. Production performance, egg quality and intestinal histology in laying hens fed dietary dried fermented ginger. International Journal of Poultry Science, vol. 8, no. 11, pp. 1078-1085. http://dx.doi.org/10.3923/ ijps.2009.1078.1085.

JOLAD, S.D., LANTZ, R.C., SOLYOM, A.M., CHEN, G.J., BATES, R.B. and TIMMERMANN, B.N., 2004. Fresh organically grown ginger (Zingiber officinale): composition and effects on LPS-induced PGE2 production. Phytochemistry, vol. 65, no. 13, pp. 19371954. http://dx.doi.org/10.1016/j.phytochem.2004.06.008. PMid:15280001.

KAMAL, A.M. and RAGAA, N.M., 2014. Effect of dietary supplementation of organic acids on performance and serum biochemistry of broiler chicken. Nature and Science, vol. 12, no. 2, pp. 38-45

KARANGIYA, V.K., SAVSANI, H.H., PATIL, S.S., GARG, D.D., MURTHY, K.S., RIBADIYA, N.K. and VEKARIYA, S.J., 2016. Effect of dietary supplementation of garlic, ginger and their combination on feed intake, growth performance and economics in commercial broilers. Veterinary World, vol. 9, no. 3, pp. 245-250. http:// dx.doi.org/10.14202/vetworld.2016.245-250. PMid:27057106.

KHAN, R.U., NAZ, S., NIKOUSEFAT, Z., TUFARELLI, V., JAVDANI, M., QURESHI, M.S. and LAUDADIO, V., 2012. Potential applications of ginger (Zingiber officinale) in poultry diets. World's Poultry Science Journal, vol. 68, no. 2, pp. 245-252. http://dx.doi. org/10.1017/S004393391200030X.

KHAN, S.H. and IQBAL, J., 2016. Recent advances in the role of organic acids in poultry nutrition. Journal of Applied Animal Research, vol. 44, no. 1, pp. 359-369. http://dx.doi.org/10.108 0/09712119.2015.1079527.

KOKOLAKIS, G., PANAGIS, L., STATHOPOULOS, E., GIANNIKAKI, E., TOSCA, A. and KRÜGER-KRASAGAKIS, S., 2008. From the protein to the graph: how to quantify immunohistochemistry staining of the skin using digital imaging. Journal of Immunological Methods, vol. 331, no. 1-2, pp. 140-146. http://dx.doi.org/10.1016/j. jim.2007.12.013. PMid:18234207.

KUCUKKURT, I., AVCI, G., ERYAVUZ, A., BAYRAM, I., CETINGUL, I.S., AKKAYA, A.B. and UYARLAR, C., 2009. Effects of Supplementation of Aniseed (Pimpinella anisum L.) at various amounts to diets on lipid peroxidation, antioxidant activity and some biochemical parameters in laying quails (Coturnix coturnix japonica). Kocatepe Veterinary Journal, vol. 2, no. 1, pp. 1-5. 
LINDSTEDT, I., 2018. Ginger and diabetes: a mini-review. Archives of General Internal Medicine, vol. 2, no. 2, pp. 29-33.

MAHADY, G.B., PENDLAND, S.L., YUN, G.S., LU, Z.Z. and STOIA, A., 2003. Ginger (Zingiber officinale Roscoe) and the gingerols inhibit the growth of Cag A+ strains of Helicobacter pylori. Anticancer Research, vol. 23, no. 5A, pp. 3699-3702. PMid:14666666.

MALEKIZADEH, M., MOEINI, M.M. and GHAZI, S., 2012. The effects of different levels of ginger (Zingiber officinale Rosc) and turmeric (Curcuma longa Linn) rhizomes powder on some blood metabolites and production performance characteristics of laying hens. Journal of Agricultural Science and Technology, vol. 14, no. 1, pp. 127-134.

MIYA, A., SITHOLE, A.N., MTHETHWA, N., KHANYILE, M. and CHIMONYO, M., 2019. Response in carcass yield, organ weights, and gut morphology of broiler chickens to incremental levels of Vachellia tortilis leaf meal. Canadian Journal of Animal Science, vol. 100, no. 2, pp. 282-291. http://dx.doi.org/10.1139/ cjas-2019-0041.

MOHAMED, A.B., AL-RUBAEE, M.A.M. and JALIL, A.Q., 2012. Effect of ginger (Zingiber officinale) on performance and blood serum parameters of broiler. International Journal of Poultry Science, vol. 11, no. 2, pp. 143-146. http://dx.doi.org/10.3923/ ijps.2012.143.146.

NATIONAL RESEARCH COUNCIL - NRC, 1994. Nutrient requirements of poultry. 9th revised edition. Washington, DC: National Academy Press.

NIDAULLAH, H., DURRANI, F.R., AHMAD, S., JAN, I.U. and GUL, S., 2010. Aqueous extract from different medicinal plants as anticoccidial, growth promotive and immunostimulant in broilers. Journal of Agricultural and Biological Science, vol. 5 no. 1, pp. 53-59.

OLADELE, O.A., EMIKPE, B.O. and BAKARE, H., 2012. Effects of dietary garlic (Allium sativum Linn.) supplementation on body weight and gut morphometry of commercial broilers. International Journal of Morphology, vol. 30, no. 1, pp. 238-240. http://dx.doi. org/10.4067/S0717-95022012000100042.

ONIMISI, P.A., DAFWANG, I.I. and OMAGE, J.J., 2005. Growth performance and water consumption pattern of broiler chicks fed graded levels of ginger waste meal. Journal of Agriculture, Forestry and the Social Sciences, vol. 3, no. 2, pp. 113-119.

ONU, P.N., 2010. Evaluation of two herbal spices as feed additives for finisher broilers. Biotechnology in Animal Husbandry, vol. 26, no. 5-6, pp. 383-392. http://dx.doi.org/10.2298/BAH10063830.

PANDA, A.K., RAO, S.V., RAJU, M.V.L.N. and SUNDER, G.S., 2009. Effect of butyric acid on performance, gastrointestinal tract health and carcass characteristics in broiler chickens. Asian-Australasian Journal of Animal Sciences, vol. 22, no. 7, pp. 1026-1031. http:// dx.doi.org/10.5713/ajas.2009.80298.

PHIRI, N., MAINDA, G., MUKUMA, M., SINYANGWE, N.N., BANDA, L.J., KWENDA, G., MUONGA, E.M., FLAVIEN, B.N., MWANSA, M., MUNYEME, M. and MUMA, J.B., 2020. Antibiotic-resistant Salmonella species and Escherichia coli in broiler chickens from farms, abattoirs and open markets in selected districts of Zambia. Journal of Epidemiological Research, vol. 6, no. 1, pp. 13-21.

PIRGOZLIEV, V., ROSE, S.P. and IVANOVA, S., 2019. Feed additives in poultry nutrition. Bulgarian Journal of Agricultural Science, vol. 25 , no. 1, pp. 8-11.

PLATEL, K. and SRINIVASAN, K., 2000. Influence of dietary spices and their active principles on pancreatic digestive enzymes in albino rats. Food, vol. 44, no. 1, pp. 42-46. http://dx.doi.org/10.1002/ (SICI)1521-3803(20000101)44:1<42::AID-FOOD42>3.0.CO;2-D. PMid:10702999.
PRIYA RANI, M., PADMAKUMARI, K.P., SANKARIKUTTY, B., LIJO CHERIAN, O., NISHA, V.M. and RAGHU, K.G., 2011. Inhibitory potential of ginger extracts against enzymes linked to type 2 diabetes, inflammation and induced oxidative stress. International Journal of Food Sciences and Nutrition, vol. 62, no. 2, pp. 106-110. http://dx.doi.org/10.3109/09637486.2010 .515565 . PMid:20874376.

QORBANPOUR, M., FAHIM, T., JAVANDEL, F., NOSRATI, M., PAZ, E., SEIDAVI, A., RAGNI, M., LAUDADIO, V. and TUFARELLI, V., 2018. Effect of dietary ginger (Zingiber officinale Roscoe) and multi-strain probiotic on growth and carcass traits, blood biochemistry, immune responses and intestinal microflora in broiler chickens. Animals, vol. 8, no. 7, pp. 117. http://dx.doi. org/10.3390/ani8070117. PMid:30011890.

RABABAH, T.M., HETTIARACHCHY, N.S. and HORAX, R., 2004. Total phenolics and antioxidant activities of fenugreek, green tea, black tea, grape seed, ginger, rosemary, gotu kola, and ginkgo extracts, vitamin E, and tert-butylhydroquinone. Journal of Agricultural and Food Chemistry, vol. 52, no. 16, pp. 5183-5186. http://dx.doi.org/10.1021/jf049645z. PMid:15291494.

RAWAT, S., 2015. Evaluation of synergistic effect of Ginger, Garlic, Turmeric extracts on the antimicrobial activity of drugs against bacterial phatogens. International Journal of Biopharmaceutics, vol. 6, no. 2, pp. 60-65.

REHMAN, Z.U., HAQ A.U., AKRAM, N., EL-HACK, M.E.A., SAEED, M., REHMAN, S.U., MENG, C., ALAGAWANY, M., SAYAB, M., DHAMA, K. and DING, C., 2016. Growth performance, intestinal histomorphology, blood hematology and serum metabolites of broilers chickens fed diet supplemented with graded levels of acetic acid. International Journal of Pharmacology, vol. 12, no. 8, pp. 874-883. http://dx.doi.org/10.3923/ijp.2016.874.883.

REHMAN, Z.U. and HAQ, A.U., 2014. Effect of garlic and ginger supplementation on broiler performance. Germany: LAP LAMBERT Academic Publishing. Available from: https://www.amazon. com/Effect-garlic-supplementation-broiler-performance/ $\mathrm{dp} / 3659565466$.

SHEWITA, R.S. and TAHA, A.E., 2018. Influence of dietary supplementation of ginger powder at different levels on growth performance, haematological profiles, slaughter traits and gut morphometry of broiler chickens. South African Journal of Animal Science, vol. 48, no. 6, pp. 997-1008.

TAG, H., ALI, A.L., ABDELWAHAB, M. and NABIL, Z., 2015. Hypoglycemic, antihyperlipidemic and antioxidant effects of ginger and alpha-lipoic acid in experimentally diabetic rats. Catrina: The International Journal of Environmental Sciences, vol. 12, no. 1, pp. 7-15.

THAYALINI, K., SHANMUGAVELU, S., SAMINATHAN, P.M., SITIMASIDAYU, M.S., NORIDAYUSNI, Y., ZAINMUDDIN, H., NURUL AKMAI, C. and WONG, H., 2011. Effects of Cymbopogon citratus leaf and Zingiber officinale rhizome supplementation on growth performance, ileal morphology and lactic acid concentration in broilers. Malaysian Journal of Animal Science, vol. 14, pp. 43-49.

TOGHYANI, M., TOGHYANI, M., GHEISARI, A., GHALAMKARI, G. and EGHBALSAIED, S., 2011. Evaluation of cinnamon and garlic as antibiotic growth promoter substitutions on performance, immune responses, serum biochemical and haematological parameters in broiler chicks. Livestock Science, vol. 138, no. 1-3, pp. 167-173. http://dx.doi.org/10.1016/j.livsci.2010.12.018.

VALIOLLAHI, M.R., RAHIMIAN, Y., RAFIEE, A. and MIRI, Y., 2014. Effect use ginger (Zingiber officinale), black pepper (Piper nigrum $\mathrm{L}$ ) powders on performance, some blood parameters and antibody titer against new castle vaccine on broiler chicks. European Journal of Zoological Research, vol. 3, no. 3, pp. 61-66. 
VARGA, C., GUERIN, M.T., BRASH, M.L., SLAVIC, D., BOERLIN, P. and SUSTA, L., 2019. Antimicrobial resistance in fecal Escherichia coli and Salmonella enterica isolates: a two-year prospective study of small poultry flocks in Ontario, Canada. BMC Veterinary Research, vol. 15, no. 1, pp. 464. http://dx.doi.org/10.1186/ s12917-019-2187-z. PMid:31864357.

VINUS, R.D., SHEORAN, N., MAAN, N. and TEWATIA, B., 2018. Potential benefits of herbal supplements in poultry feed: a review. The Pharma Innovation Journal, vol. 7, no. 6, pp. 651-656.

WALDROUP, P.W., OVIEDO-RONDON, E.O. and FRITTS, C.A., 2003. Comparison of Bio-Mos and antibiotic feeding programs in broiler diets containing copper sulfate. International Journal of Poultry Science, vol. 2, no. 1, pp. 28-31.

ZHANG, G.F., YANG, Z.B., WANG, Y., YANG, W.R., JIANG, S.Z. and GAI, G.S., 2009. Effects of ginger root (Zingiber officinale) processed to different particle sizes on growth performance, antioxidant status, and serum metabolites of broiler chickens. Poultry Science, vol. 88, no. 10, pp. 2159-2166. http://dx.doi. org/10.3382/ps.2009-00165. PMid:19762870.

ZHANG, X.F. and TAN, B.K.H., 2000. Effects of an ethanolic extract of Gynura procumbens on serum glucose, cholesterol and triglyceride levels in normal and streptozotocin-induced diabetic rats. Singapore Medical Journal, vol. 41, no. 1, pp. 9-13. PMid:10783673. 